International Research Journal of Management, IT \& Social Sciences
Available online at https://sloap.org/journals/index.php/irjmis/
Vol. 7 No. 6, November 2020, pages: 54-65
$\begin{aligned} & \text { ISSN: 2395-7492 } \\ & \text { https://doi.org/10.21744/irjmis.v7n6.1005 }\end{aligned}$

\title{
Types of Personality, Audit Structure and Transformational Leadership Styles Moderate the Effect of Organizational Commitments on Auditor Performance
}

I Dewa Gde Dharma Suputra a Ni Luh Sari Widhiyani ${ }^{b}$

Article history:

Submitted: 18 July 2020

Revised: 9 August 2020

Accepted: 27 September 2020

\section{Keywords:}

audit structure;

auditor performance;

organizational commitment;

personality type;

transformational leadership

style;

\begin{abstract}
The purpose of this study was to confirm the effect of organizational commitment on auditor performance. Meanwhile, the specific objective of this study was to determine the ability of contingency factors, such as personality type, audit structure, and transformational leadership style to moderate the effect of organizational commitment on auditor performance. The study population in this study were auditors of the public accounting firm / KAP in the Province of Bali, then the research sample was determined using a purposive sampling method. Furthermore, primary data were collected in the form of respondents' perceptions using a modified questionnaire from previous researchers and tested for compliance with the instrument's validity and reliability test requirements. Then, the collected data were tabulated and analyzed using the Moderated Regression Analysis (MRA) technique through the following stages: classical assumption test, model feasibility test (F test), determination coefficient analysis (Ajd. R2), research hypothesis testing ( $\mathrm{t}$ test) is good for its partial and moderate influence. The results of the study found that organizational commitment improves auditor performance. Personality type is not able to strengthen the positive effect of organizational commitment on auditor performance. Audit structure and transformational leadership style reinforce the positive effect of organizational commitment on auditor performance.
\end{abstract}

International research journal of management, IT and social sciences (C) 2020. This is an open access article under the CC BY-NC-ND license (https://creativecommons.org/licenses/by-nc-nd/4.0/).

Corresponding author:

I Dewa Gde Dharma Suputra,

Suputra, I.D.G.D.

Economics and Business Faculty, Udayana University, Bali - Indonesia

Email address: dharma.suputra@ymail.com

Economics and Business Faculty, Udayana University, Bali - Indonesia

Economics and Business Faculty, Udayana University, Bali - Indonesia 


\section{Introduction}

Audit failure cases in recent decades have created a crisis of public confidence regarding the ability of the accounting profession to audit financial reports. The emergence of this crisis is reasoned by a few financial reports of a company that receive unqualified opinion, but instead face problems in the continuity of its business after the opinion is issued (Fitriani and Daljono, 2012). The accounting manipulation scandal involving a number of large companies in America such as Enron, Tyco, Global Crossing and WorldCom as well as several large companies in Indonesia such as Kimia Farma and Lippo Bank, which previously had high audit quality, led to a decline in public trust, especially the financial community (Susiana and Herawaty, 2007). A failed audit case has the potential to harm the audit profession, such as decreased professionalism, loss of public trust and social credibility and the reputation of public accountants (Hartanto, 2001). Therefore, various efforts to reduce the expectation gap in the quality of auditors are urgently needed by uncovering various variables that trigger problems. There are three factors that affect the performance of auditors, namely individual, task, and environmental factors (Bonner \& Sprinkle, 2002). Individual factors include the characteristics of individual auditors who carry out tasks such as motivation, personality, self-confidence, knowledge and ability of auditors. Job or professional job factors, such as: the complexity and structure of the task, while environmental factors include all conditions, circumstances, and influences surrounding auditors who perform certain tasks, such as time pressure, accountability, engagement objectives, and feedback Furthermore, Pamilih (2014) argues that a person's success and performance in his job can be determined from several things, namely the level of competence, professionalism and also commitment to the field of work he is engaged in. An auditor who is committed to the organization will show good attitudes and behavior at the place where he works, the auditor will have a great sense of defending his organization, trying to improve his performance and having certain confidence in realizing organizational goals (Arifah, 2013). Therefore, commitment will create a sense of belonging (sense of belonging) for the auditors to the organization. Thus it can be said that auditors with high organizational commitment will have the determination and various efforts to improve their performance for the public accounting firm / KAP where they work.

Research on the effect of organizational commitment on auditor performance has been conducted by several researchers and found different results. Meyer (1989), Fernando, et al. (2005), Hian (2009), Lawalata, et al. (2010), Sapariyah (2011), Arifah (2013), and Suryana (2013) in their research found that organizational commitment has a positive and significant effect on auditor performance. Meanwhile, research conducted by Somers and Birnbaum (2008), Siahaan (2010), and Gummala (2014) revealed that organizational commitment has no effect on auditor performance.

The inconsistent results of previous studies motivated researchers to have the role of research variables that play a role in moderating the effect of organizational commitment on auditor performance. As stated by Govindarajan (1986), it is possible that there is no unified research result depending on certain factors or better known as contingency factors. Murray (1990) explains that in order to reconcile conflicting results, a contingency approach is needed to identify other variables that act as moderators or mediators in the research model. The determination of research variables that are strongly suspected of being able to moderate the effect of organizational commitment on auditor performance cannot be separated from the attribution theory by Heider (1958) which emphasizes that a person's behavior is determined by a combination of internal forces and external forces (Lubis, 2011; Andiola, 2014; Bass \& Steidlmeier, 1999; Svanberg \& Öhman, 2015). One of the internal strengths is the personality type and the external strength is the audit structure and transformational leadership style. Personality type is a factor that is often associated with efforts to increase professional skepticism and the ability of auditors to detect fraud. Noviyanti (2008) states that a person's personality type is one of the factors that determines the attitude of the individual, including the skepticism found in the individual. Auditors with the ST-NT personality type based on the Myers-Briggs theory tend to be more skeptical. Because the auditor has ST-NT personality traits who always think sensibly in making decisions based on the facts. So that auditors with the ST-NT personality type are more skeptical to detect fraud compared to other personality types so that it is more likely to achieve better audit performance. Hayati et al. (2013) in their research found that there was a positive effect of personality type on the performance of KAP auditors in the cities of Padang and Pekanbaru. The role of personality types in auditing is also revealed from the research of Pincus (1991), Kristianti (2012) who found that personality types improve the quality of audit judgments made by auditors. Based on the conception and empirical research that has been described, it can be seen that the ST-NT personality type has a positive effect on auditor performance. An auditor with the ST-NT personality type has a strong opportunity to increase the positive effect of organizational commitment on auditor performance, on the other hand, an auditor with a personality type other than

Suputra, I. D. G. D. ., \& Widhiyani , N. L. S. . (2020). Types of personality, audit structure and transformational leadership styles moderate the effect of organizational commitments on auditor performance. International

Research Journal of Management, IT and Social Sciences, 7(6), 54-65. https://doi.org/10.21744/irjmis.v7n6.1005 
ST-NT is not sufficient to increase the positive effect of organizational commitment on auditor performance. What is the reality, of course, depends on the test results in this study.

Furthermore, the external factor, namely the work environment that contributes to the performance of the auditor, is the audit structure, which is a systematic approach to auditing characterized by audit determination steps, logical sequence procedures, decisions, documentation, and using a set of audit tools and policies, which comprehensive and integrated to help auditors conduct audits. This relates to work flow coordination, authority, communication and adaptability so that users of the audit structure approach are expected to improve auditor performance for the better (Bamber et al., 1989; Bowrin, 1998). Several researchers have conducted studies on the effect of audit structure on auditor performance, for example, Hanif (2013), and Fanani et al. (2007) who found that the audit structure has a positive and significant effect on performance. The same results were found in the research of Putra and Gayatri and Suputra (2016), and Aiman (2017). Based on the conception description and empirical research that has been presented, it is revealed that the audit structure has a positive effect on auditor performance. An auditor in the audit process equipped with an audit structure will increase his confidence and enthusiasm so that it will stimulate high commitment in order to achieve more audit performance. Transformational leadership style, another situational factor, which emphasizes the importance of a leader to create a vision and an environment that motivates subordinates to excel beyond their expectations (Sina, 2013). Tintami (2012) states that transformational leadership is a process in which leaders and followers mutually enhance themselves to higher morality and motivation. Transformational leadership style focuses more on moral formation and providing motivation. Leaders who use this leadership style are usually close to employees so that employees feel more motivated to reach higher levels. So that if each auditor has a transformational leadership style, the quality of the resulting audits will be better, it is due to good coordination or cooperation among auditors. The results of research conducted by Tintamin et al. (2012) revealed that transformational leadership styles improve auditor performance. Sina (2013) also state that there is a positive influence between transformational leadership style and auditor performance. The same results were also found in the research of Aris \& Dodik (2016) and Sendhi \& Badera (2017). The brief explanation of the conception and empirical research above reveals that the three contingency factors, namely: personality type, audit structure, and transformational leadership style, are able to improve performance so that it has the potential to moderate the positive influence of organizational commitment on auditor performance. The moderation test of these three contingency factors on the effect of organizational commitment on auditor performance also differentiates this study from research previously carried out by Hayati et al. (2013), Pincus (1991), Kristianti (2012) which examines the partial effect of personality types on the quality of the audit judgment made by the auditors. It is also different from the research of Hanif (2013), Fanani et al. (2007), Putra and Aiman (2017) who examined the partial effect of audit structure on auditor performance. And lastly, this study is different from research conducted by Aris and Dodik (2016) and Sendhi and Badera (2017), Putra and Dodik (2012) and Gayatri and Suputra (2016) and Aiman (2017) which tested the partial effect of transformational leadership styles. on auditor performance.

\section{Literature Review}

\section{Attribution Theory}

Attribution theory studies the process by which a person interprets an event, reasons, or causes of behavior. This theory was developed by Heider (1958) who argued that a person's behavior is determined by a combination of internal forces, namely factors originating from within a person, such as ability and effort, and external forces, namely factors -factors originating from outside such as difficulties in work (Lubis, 2011; Szczepańska-Woszczyna, 2015; Yucel \& Bektas, 2012).

Attribution theory provides an explanation of the process of how to determine the causes or motives for one's behavior (Gibson et al., 1994). This theory is directed to develop an explanation of the ways we judge people differently, depending on what meaning we attribute (attribute) to a particular behavior. This theory refers to how a person explains the causes of other people's behavior or himself (Luthans, 1998), which is determined whether from internal or external, the effect will be seen on individual behavior (Gibson et al., 1994). The causes of this behavior in social perception are known as dispositional attributions and situational attributions (Luthans, 1998; Gibson et al., 1994; Baron and Greenberg, 1993) or internal and external causes. Dispositional attributions or internal causes refer to aspects of individual behavior, something that is in a person such as personal traits, self-perception, abilities, motivation. Situational attributions or external causes refer to the environment that affects behavior, such as social conditions, social values, and people's views. 
Internal and external attributions have been stated to have a strong influence on individual performance evaluation, for example determining how supervisors treat their subordinates, and affecting individual attitudes and satisfaction with work Reed et al. (1994) emphasize the existence of "a number of attributes", which naturally apply internally in the organization, affecting employee attitudes, especially those related to their work and commitment to the organization. Internal attributions include individual perceptions of locus of control, while external attributions include social constructs that view the role that a person accepts based on gender, as a result of a social perspective.

\section{Auditor Performance}

The performance of a quality KAP auditor is largely determined by the performance of the accountants. The public accounting profession is a profession of public trust. The accounting profession has a very important role in providing reliable financial information for the government, creditors, investors, debtors, shareholders, employees, as well as for the public and other interested parties (Suseno, 2013). In other words, the accounting profession is very important for the stakeholders of a company. From the public accounting profession, what the public expects is a free and impartial assessment of the information in the financial statements presented by company management (Mulyadi, 2009). Warren \& Alzola (2008) stated that generally auditors have the responsibility to act objectively. Increasing the reliability of corporate financial reports is the responsibility of the public accountant profession, so that reliable financial information as a basis for decision making can be obtained by the public. Therefore, auditors are highly required to maximize performance on clients and other users of audited financial statements. According to Rahmawati (2011), the accounting profession has a very important role for society in relation to the duties and responsibilities of auditors.

Auditor performance is the ability of an auditor to produce findings or results from audit activities on financial management and responsibility carried out in one team (Yanhari, 2007 in Satwika, 2015). Auditor performance is an act or implementation of audit tasks that have been completed by the auditor within a certain period of time. Goldwasser (1993) in Hanif (2013) states that the achievement of better auditor performance must be in accordance with certain standards and time periods, namely: the quality of completing work by working based on all abilities and skills and knowledge possessed by auditors, work results that can be completed with the target that is the responsibility of the auditor's job and the ability to take advantage of the facilities and infrastructure to support the work and finally the timeliness available to complete the work.

\section{Contingency Approach}

The contingency approach can be used to analyze the design and management accounting systems to provide information that companies can use for a variety of purposes. This theory explains that a management control can be applied to the characteristics of any company. Fisher (1998) argues that this contingency approach reveals that the planning and use of a management control system design depends on the characteristics of the organization and the environmental conditions in which the system is implemented. The contingency approach attracts researchers because they want to know whether the level of reliability of a management accounting system will always have the same effect on every condition or not. Based on the contingency approach, there are other situational factors that may interact with each other in certain conditions.

The contingency approach used by researchers is to provide input on the factors that should be considered in the research design. Researchers are interested in using a contingency approach because they want to find out whether the level of reliability of the independent variable always has the same effect on each condition or not on the dependent variable. The contingency approach in this research tries to identify and measure the conditions in which all things might influence each other and will interact with each other under certain conditions. This approach is in line with the development of the argument that organizational commitment, personality types, and transformational leadership styles are situational factors that have the potential to moderate the effect of audit structures on auditor performance.

\section{Hypotheses}

\section{Organizational Commitment and Its Effect on Auditor Performance}

Organizational commitment is defined as a combination of attitudes and behavior. Organizational commitment is an attitude that reflects employee loyalty to the organization and is sustainable so that organizational members can express

Suputra, I. D. G. D. ., \& Widhiyani , N. L. S. . (2020). Types of personality, audit structure and transformational leadership styles moderate the effect of organizational commitments on auditor performance. International

Research Journal of Management, IT and Social Sciences, 7(6), 54-65. https://doi.org/10.21744/irjmis.v7n6.1005 
their concern for the organization and its continued success and progress (Luthans, 1998). In line with Luthans, Angel and Perry (1981) and Porter et al. (1974) said that strong organizational commitment will encourage individuals to strive to achieve organizational goals. In addition, high organizational commitment will increase high performance as well. Organizational commitment will create a sense of belonging (sense of belonging) for workers to the organization.

An auditor who is committed to the organization will show a good leadership attitude and style towards the place where he works, the auditor will have a great sense of defending his organization, trying to improve his performance and having certain confidence in realizing organizational goals (Arifah, 2012). Meyer et al. (1989) and Fernando et al. (2005) in their research found a positive influence on organizational commitment on auditor performance. The same results were also revealed from research conducted by Akriyanto (2012), Yuskar and Selly Devisia (2011), Ananta and Ramantha (2015), and Setiadi and Rasmini (2016).

Based on the theoretical exposure and the results of the empirical research above, it can be clearly seen that there is an influence of organizational commitment on auditor performance. The stronger the organizational commitment of an auditor, the greater the audit performance. Thus, the following research hypothesis can be developed:

H1: Organizational commitment has a positive effect on auditor performance.

\section{Personality Type and Their Ability to Moderate the Effect of Organizational Commitment on Auditor Performance}

In various psychology literature, the classic definition of G.W. Allport regarding the meaning of personality (personality) is the most frequently used. Allport explained that: "Personality is a dynamic organization, inside the person, of psychophysical systems that create the person 's characteristic patterns of behavior, thoughts and feelings." A person's personality is formed by two main factors, namely (1) heredity or genetic factors. are the basic factors of shaping a person's personality, and (2) environmental factors, namely factors that affect a person's personality based on where a person grows and grows. In this study, personality types are grouped based on the Myers-Briggs Type Indicator (MBTI). The Myers-Briggs Type Indicator (MBTI) was developed by Katharine Cook Briggs and her daughter, Isabel Briggs Myers, based on the personality theory of Carl Gustav Jung (Fordham, 2004). In the MBTI, human personality types are divided into 4 pairs of preferences (a summary of how to measure the Myers-Briggs personality type can be seen in Appendix 7, namely: (1) Extraversion and Introversion preferences (E and I), (2) Sensing and Intuition preferences ( $\mathrm{S}$ and N), (3) Thinking and Feeling preferences ( $\mathrm{T}$ and F), and (4) Judging and Perceiving preferences ( $\mathrm{J}$ and $\mathrm{P}$ ). Auditors with a combination of ST and NT personality types are auditors who have professional skepticism and auditors who will further improve their ability to detect when faced with symptoms of fraud compared to auditors with other personality types, thereby improving the auditor's performance. Noviyanti (2008) research has proven that auditors with ST and NT personality types are auditors who have higher professional skepticism than auditors with other personality types, so that in the end it will improve the auditor's performance. The same results were also revealed by research previously conducted by Donelly et al. (2003), Putri et al. (2013), Herliansyah and Ilyas (2006), and Arum (2008). Based on the logical thinking framework and the results of previous research that has been presented, it can be seen clearly that there is a positive influence of ST and NT personality types on auditor performance so that it is thought to have the potential for moderation on the effect of organizational commitment on auditor performance. An audit with the ST and NT personality types can certainly encourage stronger organizational commitment in order to improve the quality of the audit he does. So that with this rationale, the following research hypothesis can be developed:

$\mathrm{H}_{2}$ : Personality type reinforces the positive effect of organizational commitment on auditor performance.

\section{Audit Structure and Its Ability to Moderate the Effect of Organizational Commitment on Auditor Performance}

The definition of audit structure according to Bowrin (1998) is a systematic approach to auditing characterized by steps in determining the audit, logical sequence procedures, decisions, documentation, and using a comprehensive and integrated set of audit tools and policies to help auditors conduct audits. Muslim A. (2002) explains that the audit structure includes what must be done, instructions on how work must be completed, tools for coordination, tools for audit supervision and control and tools for assessing the quality of work carried out. Understanding of a good audit structure can improve auditor performance. This is because the audit techniques and procedures used will be more effective and efficient resulting in better performance. Bamber et al. (1989) who conducted a study with a sample of 121 KAP managers, stated that public accounting firms that use an audit structure will improve auditor performance. Conversely, a public accounting firm that does not use an audit structure has the potential to increase role conflict and the perceived role ambiguity of its audit staff. Likewise, research by Stuart \& Doughlas (2004) found the effect of 
audit structure on auditor performance on high and low task complexity with a sample of 81 KAP auditors. Furthermore, the research of Fanani et al. (2007) on 68 KAP auditors in East Java, revealed that the audit structure has a positive effect on auditor performance. The above conceptual descriptions and empirical research results indicate that the audit structure has a positive effect on auditor performance. If an auditor's audit process is supported by an adequate audit structure, he will be able to strengthen organizational commitment to achieve better audit performance. Thus, the following research hypotheses can be developed:

$\mathrm{H}_{4}$ : The audit structure strengthens the positive influence of organizational commitment on auditor performance.

Transformational Leadership Style and Its Ability to Moderate the Effect of Organizational Commitment on Auditor Performance

Transformational leadership style is a leadership style that inspires followers to be involved, committed, and has a vision and goals for their organization, encourages followers to be innovative in solving organizational problems, and supports followers to have competence in leadership through coaching and supervision (Indrayanto et al. 2013). Transformational leadership is a leader who inspires followers to go beyond their personal interests and who is able to have a profound and extraordinary impact on followers (Cavazott et al. 2011). The leadership style is one of the important factors that can affect the performance of subordinates. Adeyemi \& Fagbemi (2010) emphasize that leadership has a positive impact on auditor performance. The results of research conducted by Tintamin et al. (2012) found that transformational leadership styles improve auditor performance. This fact is confirmed by the results of research by Sina (2013) which also revealed a positive influence of transformational leadership on the quality or performance of auditors. Exposure to logical thinking frameworks and results of previous research can clearly identify the positive influence of transformational leadership styles on auditor performance. When an auditor is supervised by a supervisor or manager with a transformational leadership style, he will be able to motivate himself to strengthen organizational commitment to achieve maximum audit performance. Thus, the following research hypotheses can be developed:

$\mathrm{H}_{4}$ : Transformational leadership style reinforces the positive influence of the audit structure on auditor performance.

\section{Materials and Methods}

This research was conducted at a public accounting firm (KAP) located in Bali which is a member of the Indonesian Institute of Public Accountants (IAPI). To test the research hypothesis, research methods are described which include: determination of population and types, and data sources, as well as data collection methods, identification and operational definitions, and measurement of research variables. This study uses response data collected using a questionnaire that has met the requirements for the validity and reliability of the instrument. Furthermore, the collected data is tabulated and tested for compliance with the classical assumption test, model feasibility test, and coefficient of determination analysis. Then the research hypothesis is tested using MRA (moderated regression analysis) analysis techniques to determine the partial effect of organizational commitment on auditor performance and the ability to determine the ability of ST and NT personality types, audit structure, and transformational leadership style to moderate the effect of organizational commitment on auditor performance.

\section{Results and Discussions}

\section{Descriptive Analysis}

Descriptive statistics in this study were tested to provide information about the characteristics of the research variables. The minimum value indicates the smallest or lowest value in a data set. The maximum value indicates the largest or highest value in a data set. The average (mean) is the most common way to measure the central value of a data distribution under study. Standard deviation is a measure that shows the standard deviation of the observed data from the average data.

Suputra, I. D. G. D. ., \& Widhiyani , N. L. S. . (2020). Types of personality, audit structure and transformational leadership styles moderate the effect of organizational commitments on auditor performance. International Research Journal of Management, IT and Social Sciences, 7(6), 54-65. https://doi.org/10.21744/irjmis.v7n6.1005 
Tabel 1

Descriptive statistics

\begin{tabular}{lccccc}
\hline & N & Min & Max & Mean & $\begin{array}{c}\text { Std. } \\
\text { Deviation }\end{array}$ \\
\hline Organizational Commitment (OC) & 53 & 2,00 & 5,00 & 3,95 & 1,07 \\
Personality type (PT) & 53 &, 00 & 1,00 & 0,81 & 0,39 \\
Audit Structure (AS) & 53 & 2,00 & 5,00 & 3,87 & 0,93 \\
Transformational Leadership Style (TLS) & 53 & 2,20 & 5,00 & 3,93 & 1,04 \\
Auditor Performance (AP) & 53 & 2,00 & 5,00 & 3,90 & 1,03 \\
\hline
\end{tabular}

\section{Hypothesis test}

The research instrument has tested the validity and reliability test and to test the validity the results obtained that the Pearson correlation of each respondent's statement is greater than 0.30 . Thus, all statement items from this research variable have met the valid requirements so that they are suitable for use in research. While the reliability test results show that all research instruments, namely Organizational Commitment (OC), Personality type (PT), Audit Structure (AS), Transformational Leadership Style (TLS), Auditor Performance (AP) have a Cronbach's Alpha coefficient greater than 0.70 so that it can be said to be reliable and feasible. used in research. This means that if the measurement is carried out more than once for the same symptom, the measurement will give consistent results. Before the multiple linear regression analysis is carried out, the regression model that is made must go through the classical assumption test first so that the resulting equation meets the BLUE (Best, Linear, Unbias, Estimator) rules. If the classical assumption test is not carried out before data processing, the resulting regression model equation is doubtful for its ability to produce accurate predictions. A good regression model is a regression model in which there are no data problems with abnormal distribution, multicollinearity problems and heteroscedasticity problems. The results of the normality test show that the coefficient value of Asymp.Sig. (2-tailed) of 0.200 is greater than the alpha value of 0.05 . This shows that the variables Organizational Commitment (OC), Personality type (PT), Audit Structure (AS), Transformational Leadership Style (TLS), Auditor Performance (AP) are normally distributed. For the multicollinearity test, it shows that all independent variables in this study, namely Organizational Commitment (OC), Personality type (PT), Audit Structure (AS), Transformational Leadership Style (TLS) show a tolerance value greater than 0.10 and VIF less than 10. This indicates that the regression equation model has no symptoms (independent) multicollinearity between independent variables. While the results of the heteroscedasticity test show that all independent variables in this study, namely: Organizational Commitment (OC), Personality type (PT), Audit Structure (AS), Transformational Leadership Style (TLS) have a significance value above the tolerance value or an alpha value of 0.05 . This means that there is no influence between the independent variables on absolute residuals, so the regression model used does not contain heteroscedasticity symptoms. To reveal the effect of the independent and moderating variables using the MRA technique, the results of the analysis can be seen in Table 2.

Tabel 2

Moderated Regression Analysis Test Result

\begin{tabular}{|c|c|c|c|c|c|c|}
\hline & \multirow[t]{2}{*}{ Model } & \multicolumn{2}{|c|}{$\begin{array}{l}\text { Unstandardized } \\
\text { Coefficients }\end{array}$} & \multirow[t]{2}{*}{$\begin{array}{c}\text { Standardized } \\
\text { Coefficients }\end{array}$} & \multirow[t]{2}{*}{ Sig. } & \multirow{2}{*}{$\begin{array}{l}\text { Hypothesis } \\
\text { Test Result }\end{array}$} \\
\hline & & B & Std. Error & & & \\
\hline \multirow[t]{8}{*}{1} & (Constant) & $-5,546$ & ,866 & & ,866 & \\
\hline & $\mathrm{OC}$ &, 173 & 031 & 365 & 031 & $\mathrm{Ha}_{1}$ accepted \\
\hline & PT & 6,887 & ,151 & ,442 & 151 & \\
\hline & AS & 2,936 & ,006 & 2,225 & ,006 & \\
\hline & TLS & 1,888 & ,001 & 4,850 & ,001 & \\
\hline & OC_PT & , 160 & ,086 &, 572 & 086 & $\mathrm{Ha}_{2}$ rejected \\
\hline & OC_AS & 57,439 & ,002 & 4,780 & ,002 & $\mathrm{Ha}_{3}$ accepted \\
\hline & OC_TLS & 51,234 & ,003 & 4,552 & ,003 & $\mathrm{Ha}_{4}$ accepted \\
\hline
\end{tabular}

a. Dependent Variable: AP 
The results of the test on the effect of organizational commitment (OC) on auditor performance (AP) obtained a sig value. 0.012 which is smaller than alpha 0.05 with a beta score of 0.87 , which means that organizational commitment has a positive and significant effect on auditor performance. The results of this research hypothesis test failed to reject the hypothesis Ha.1 which states that organizational commitment has a positive and significant effect on auditor performance. The results of the test on the effect of organizational commitment (OC) on auditor performance (AP) obtained a sig value. 0.031 which is smaller than alpha 0.05 with a coefficient value of 0.173 , which means that organizational commitment has a positive and significant effect on auditor performance. The results of the personality type effect test on auditor performance (AP) obtained sig. 0.151 which is greater than alpha 0.05 with a coefficient value of 6.887, which means that personality type (PT) has a positive but not significant effect on auditor performance (AP).

The results of the test on the effect of the audit structure (AS) on the performance of the auditors (AP) obtained the sig value. 0.006 which is smaller than alpha 0.05 with a beta coefficient value of 2.936 , which means that the audit structure (AS) has a positive and significant effect on auditor performance (AP). The test results of the effect of transformational leadership style (TLS) on auditor performance (AP) obtained sig. 0.001 which is smaller than alpha 0.05 with a beta coefficient value of 1.888 , which means that transformational leadership style has a positive and significant effect on auditor performance. The results of the moderation test for personality type (PT) on the effect of organizational commitment (OC) on auditor performance (AP) obtained a sig. 0.086 value that is greater than alpha 0.05 with a coefficient value of 0.160 , which means that the personality type is not capable. increase the positive effect of organizational commitment on auditor performance. The results of this study reject the Ha2 hypothesis which states that personality type increases the positive effect of organizational commitment (KO) on auditor performance. The results of the audit structure moderation test on the effect of organizational commitment on auditor performance obtained a sig. 0.002 value that is smaller than alpha 0.05 with a beta coefficient value of 57.439 , which means that the audit structure increases positive influence of organizational commitment on auditor performance. The results of this study fail to reject the hypothesis Ha3 which states that audit structure increases the positive effect of organizational commitment on auditor performance. The results of the moderation test for transformational leadership style on the effect of organizational commitment on auditor performance obtained a sig. 0.003 value that is smaller than alpha 0.05 with a beta coefficient value of 51.234, which means that transformational leadership style increase the positive effect of organizational commitment on auditor performance. The results of this study fail to reject the Ha4 hypothesis which states that transformational leadership style increases the positive effect of organizational commitment on auditor performance.

\section{Discussion}

\section{Organizational commitment has a positive and significant effect on auditor performance}

The test results of this study found that organizational commitment has a positive and significant effect on auditor performance. This means that auditors with high organizational commitment will have high audit performance. These results are consistent with the research findings of Meyer (1989), Fernando et al. (2005), Hian (2009), Elya et al. (2010), Sapariyah (2011), Arifah (2013), and Suryana (2013) in their research found that organizational commitment has a positive and significant effect on auditor performance. Meanwhile, research conducted by Somers and Birnbaum (2008), Siahaan (2010), and Gummala (2014) revealed that organizational commitment has no effect on auditor performance.

The partial effect of personality types and their inability strengthens the positive effect of organizational commitment on auditor performance

The partial test results show that personality type has a positive but not significant effect on auditor performance. Furthermore, the MRA test results reveal that personality type is not able to increase the effect of organizational commitment on auditor performance. Thus, based on the classification of the moderating variables categorized by Solimun (2010), the personality type variable is a potential moderating variable. The results of this study are inconsistent with the results of Noviyanti (2008) research which states that auditors with ST and NT personality types are auditors who have higher professional skepticism than auditors with other personality types, so that in the end it

Suputra, I. D. G. D. ., \& Widhiyani , N. L. S. . (2020). Types of personality, audit structure and transformational leadership styles moderate the effect of organizational commitments on auditor performance. International

Research Journal of Management, IT and Social Sciences, 7(6), 54-65. https://doi.org/10.21744/irjmis.v7n6.1005 
will improve the auditor's performance. This result also rejects the research results of several other researchers, including: Donelly et al. (2003), Putri et al. (2013), Herliansyah and Ilyas (2006), and Arum (2008).

The partial effect of the audit structure and its ability to reinforce the positive influence of organizational commitment on auditor performance

The partial test results show that the audit structure has a positive and significant effect on auditor performance. Furthermore, the MRA test results reveal that the audit structure increases the effect of organizational commitment on auditor performance. Thus, based on the classification of the moderating variables categorized by Solimun (2010), the audit structure variable is a pseudo moderating variable. These results are also in line with the research results of Bamber et al. (1989) who conducted a study with a sample of 121 KAP managers, stated that public accounting firms that use an audit structure will improve auditor performance. Likewise, the results of this study support the research of Stuart and Doughlas (2004) which found the effect of audit structure on auditor performance on high and low task complexity with a sample of $81 \mathrm{KAP}$ auditors. Furthermore, the results of this research are also in line with the research results of Fanani et al. (2007) on 68 KAP auditors in East Java, which revealed that the audit structure had a positive effect on auditor performance.

The partial effect of transformational leadership style and its ability to strengthen the positive effect of organizational commitment on auditor performance

The partial test results indicate that transformational leadership style has a positive and significant effect on auditor performance. Furthermore, the MRA test results reveal that transformational leadership styles increase the effect of organizational commitment on auditor performance. Thus, based on the classification of the moderating variables categorized by Solimun (2010), the transformational leadership style variable is a pseudo moderating variable. These results support the results of previous research, including: Adeyemi and Fagbemi (2010) stated that leadership has a positive impact on auditor performance. The results of research conducted by Tintamin et al. (2012) found that transformational leadership styles improve auditor performance. This fact is confirmed by the results of research by Sina (2013) which also revealed a positive influence of transformational leadership on the quality or performance of auditors.

\section{Conclusion}

Based on the discussion that has been done in the previous chapter, it can be concluded as follows organizational commitment to improve auditor performance, personality type is not able to strengthen the influence of organizational commitment in improving auditor performance, the audit structure strengthens the effect of organizational commitment in improving auditor performance, transformational leadership style strengthens the influence of organizational commitment in improving auditor performance.

\section{Conflict of interest statement}

The authors declared that they have no competing interests.

Statement of authorship

The authors have a responsibility for the conception and design of the study. The authors have approved the final article.

Acknowledgments

We are grateful to two anonymous reviewers for their valuable comments on the earlier version of this paper. 


\section{References}

Adeyemi, S. B., \& Fagbemi, T. O. (2010). Audit quality, corporate governance and firm characteristics in Nigeria, 5(5), 1-11.

Agung, G. Yunilma dan Herawati. 2014. Pengaruh Indenpedensi Auditor, Komitmen Organisasi, Gaya Kepemimpinan, Budaya Organisasi Terhadap Kinerja Auditor (Studi Empiris di KAP di Kota Padang dan Pekanbaru). Jurnal Universitas Bung Hatta.

AIMAN, N. (2017). Pengaruh Struktur Audit, Independensi Auditor Dan Profesionalisme Auditor Terhadap Kinerja Auditor Pemerintah (Studi pada B adan P eme riksa K euangan $R$ epublik I ndoneisa Perwakilan Provinsi Jawa Barat) (Doctoral dissertation, Fakultas Ekonomi dan Bisnis Unpas).

Akriyanto, R. (2012). Pengaruh Independensi, Gaya Kepemimpinan, Komitmen Organisasi Dan Pemahaman Good Governance Terhadap Kinerja Auditor (Studi Empiris Pada Auditor Di Kap Wilayah Surakarta Dan Yogyakarta) (Doctoral dissertation, Universitas Muhammadiyah Surakarta).

Andiola, L. M. (2014). Performance feedback in the audit environment: A review and synthesis of research on the behavioral effects. Journal of Accounting Literature, 33(1-2), 1-36. https://doi.org/10.1016/j.acclit.2014.07.001

Arifah, N. (2012). Pengaruh Independensi Auditor, Komitmen Organisasi dan Gaya Kepemimpinan Terhadap Kinerja Auditor. Skripsi Fakultas Ekonomi dan Bisnis Universitas Hasanudin.

Arum, E. D. P. (2008). Pengaruh persuasi atas preferensi klien dan pengalaman audit terhadap pertimbangan auditor dalam mengevaluasi bukti audit. Jurnal akuntansi dan keuangan Indonesia, 5(2), 156-181.

Bamber, E. M., Snowball, D., \& Tubbs, R. M. (1989). Audit structure and its relation to role conflict and role ambiguity: An empirical investigation. Accounting review, 285-299.

Baron, R. A. Greenberg. J., 1990, Behavior in Organizations: Understanding and Managing the Human Side of Work. Aufl. Boston usw.

Bass, B. M., \& Steidlmeier, P. (1999). Ethics, character, and authentic transformational leadership behavior. The leadership quarterly, 10(2), 181-217. https://doi.org/10.1016/S1048-9843(99)00016-8

Bonner, S. E., \& Sprinkle, G. B. (2002). The effects of monetary incentives on effort and task performance: theories, evidence, and a framework for research. Accounting, organizations and society, 27(4-5), 303-345. https://doi.org/10.1016/S0361-3682(01)00052-6

Bowrin, A. R. (1998). Review and synthesis of audit structure literature. Journal of Accounting literature, 17, 40.

Cavazotte, F., Moreno, V., \& Bernardo, J. (2013). Transformational leaders and work performance: The mediating roles of identification and self-efficacy. BAR-Brazilian Administration Review, 10(4), 490-512.

Djalil, M. A. (2002). Persepsi Auditor Tentang Pengaruh Struktur Audit dan Prinsip Organisasional Terhadap Konflik dan Ambiguitas Peran. Lembaga Penelitian Universitas Syah Kuala, 5, 146-162.

Donnelly, D. P., Quirin, J. J., \& O'Bryan, D. (2003). Auditor acceptance of dysfunctional audit behavior: An explanatory model using auditors' personal characteristics. Behavioral research in accounting, 15(1), 87-110.

Ermawati, M. D., Sinarwati, N. K., \& Edy Sujana, S. E. (2014). Pengaruh Role Stress Terhadap Kinerja Auditor dengan Emotional Quotient Sebagai Variabel Moderating (Studi Empiris pada Kantor Akuntan Publik di Bali). JIMAT (Jurnal Ilmiah Mahasiswa Akuntansi) Undiksha, 2(1).

Fanani, Z., Hanif, R. A., \& Subroto, B. (2008). Pengaruh struktur audit, konflik peran, dan ketidakjelasan peran terhadap kinerja auditor. Jurnal Akuntansi dan Keuangan Indonesia, 5(2), 139-155.

Fisher, J. G. (1998). Contingency theory, management control systems and firm outcomes: past results and future directions. Behavioral research in accounting, 10, 47.

Fitriani, S. (2012). Daljono. 2012. Pengaruh Tekanan Ketaatan, Kompleksitas Tugas, Pengetahuan Dan Per-sepsi Etis Terhadap Audit Judgement. diponegoro Journal of Accounting, 1(1), 1-12.

Fordham, F. (1988). Pengantar Psikologi CG Jung. Jakarta: Bhratara Karya Aksara.

Gayatri, K. D. P., \& Suputra, I. D. (2016). Pengaruh Struktur Audit, Tekanan Waktu, Disiplin Kerja dan Komitmen Organisasi pada Kinerja Auditor. E-Jurnal Akuntansi Universitas Udayana, Mei (15), 1366-1391.

Gibson, J. L. (1996). A mile wide but an inch deep (?): The structure of democratic commitments in the former USSR. American Journal of Political Science, 396-420.

Goodwin-Stewart, J., \& Kent, P. (2006). Relation between external audit fees, audit committee characteristics and internal audit. Accounting \& Finance, 46(3), 387-404. https://doi.org/10.1111/j.1467-629X.2006.00174.x

Govindarajan, V. (1986). Impact of participation in the budgetary process on managerial attitudes and performance: Universalistic and contingency perspectives. Decision sciences, 17(4), 496-516. https://doi.org/10.1111/j.15405915.1986.tb00240.x

Suputra, I. D. G. D. ., \& Widhiyani , N. L. S. . (2020). Types of personality, audit structure and transformational leadership styles moderate the effect of organizational commitments on auditor performance. International Research Journal of Management, IT and Social Sciences, 7(6), 54-65. https://doi.org/10.21744/irjmis.v7n6.1005 
Hadi Suryana, F. (2013). Pengaruh Struktur Audit, Komitmen Organisasi Konflik Peran dan Efektivitas Penggunaan Teknologi Sistem Informasi Akuntansi Terhadap Kinerja Auditor.

Hanif, R. A. (2013). Pengaruh Struktur Audit, Konflik Peran, dan Ketidakjelasan Peran Terhadap Kinerja Auditor. Jurnal Ekonomi. September, 21(3), 1-15.

Hartanto, H. Y. (2001). Analisis Pengaruh Tekanan Ketaatan Terhadap Judgment Auditor (Doctoral dissertation, [Yogyakarta]: Universitas Gadjah Mada).

Hayati, R., Anggraini, F., \& Yunilma, Y. (2013). Pengaruh persepsi, tipe kepribadian dan kepuasan kerja terhadap kinerja auditor pada kap di wilayah kota padang dan pekanbaru.

Herawaty, S. A. (2007). Analisis pengaruh independensi, mekanisme corporate governance, dan kualitas audit terhadap integritas laporan keuangan. Makalah Simposium Nasional Akuntansi X, Makassar.

Herliansyah, Y., \& Ilyas, M. (2006). Pengaruh pengalaman auditor terhadap penggunaan bukti tidak relevan dalam auditor judgment. SNA 9 Padang, 23-26.

Ikhsan, A., \& Ghozali, I. (2006). Metodologi Penelitian Untuk Akuntansi dan Manajemen. Medan: Maju.

Indrayanto, A., Burgess, J., \& Dayaram, K. (2014). A case study of transformational leadership and para-police performance in Indonesia. Policing: An International Journal of Police Strategies \& Management.

Jaramillo, F., Mulki, J. P., \& Marshall, G. W. (2005). A meta-analysis of the relationship between organizational commitment and salesperson job performance: 25 years of research. Journal of Business Research, 58(6), 705-714. https://doi.org/10.1016/j.jbusres.2003.10.004

Kristianti, I. (2012). Pengaruh tipe kepribadian dan penerimaan perilaku disfungsional terhadap audit judgment. Universitas Kristen Satya Wacana.

Lubis, N. (2011). Analisis Faktor-Faktor Penerimaan Opini Audit Going Concern. Sekolah Tinggi Ilmu Ekonomi Perbanas. Surabaya.

Luthans, F. (1998). Organizational Behaviour: Personality and Attitude. Eight Edition. New York: McGraw Hill.

Meyer, J. P., \& Allen, N. J. (1984). Testing the" side-bet theory" of organizational commitment: Some methodological considerations. Journal of applied psychology, 69(3), 372.

Meyer, J. P., Paunonen, S. V., Gellatly, I. R., Goffin, R. D., \& Jackson, D. N. (1989). Organizational commitment and job performance: It's the nature of the commitment that counts. Journal of applied Psychology, 74(1), 152.

Moyer, J. H., Heider, C., Pevey, K., \& Ford, R. V. (1958). The effect of treatment on the vascular deterioration associated with hypertension, with particular emphasis on renal function. The American journal of medicine, 24(2), 177-192.

Mulyadi, E., Harish, S., O'Neill, J., \& Rebello, R. (2009). MRI of impingement syndromes of the shoulder. Clinical radiology, 64(3), 307-318. https://doi.org/10.1016/j.crad.2008.08.013

Murray, D. (1990). The performance effects of participative budgeting: An integration of intervening and moderating variables. Behavioral Research in accounting, 2(2), 104-123.

Noviyanti, S. (2008). Skeptisme profesional auditor dalam mendeteksi kecurangan. Jurnal Akuntansi dan Keuangan Indonesia, 5(1), 102-125.

Pincus, K. V. (1991). Audit judgment confidence. Behavioral Research in Accounting, 3(1), 39-65.

Porter, H. S., Silverman, S. M., \& Tuan, T. F. (1974). On the behavior of airglow under the influence of gravity waves. Journal of Geophysical Research, 79(25), 3827-3833. https://doi.org/10.1029/JA079i025p03827

Putra, I. G. B. W., Wira, G. B., \& Ariyanto, D. (2012). Pengaruh Independensi, Profesionalisme, Struktur Audit, dan Role Stress Terhadap Kinerja Auditor BPK RI Perwakilan Provinsi Bali. E-Jurnal Akuntansi, 1(1), 1-18.

Putri, P. A., \& Laksito, H. (2013). Pengaruh lingkungan etika, pengalaman auditor dan tekanan ketaatan terhadap kualitas audit judgment. Diponegoro Journal of Accounting, 383-393.

Rahayu, N. M. M. S., \& Badera, D. N. (2017). Pengaruh Locus Of Control Internal, Motivasi Kerja, Gaya Kepemimpinan Tranfor-masional, Komitmen Organisasi pada Kinerja Auditor. E-Jurnal Akuntansi. Universitas Udayana, 19.

Reed, S. A., Kratchman, S. H., \& Strawser, R. H. (1994). Job satisfaction, organizational commitment, and turnover intentions of United States accountants. Accounting, Auditing \& Accountability Journal. https://doi.org/10.1108/09513579410050371

Sapariyah, R. A. (2011). Pengaruh Good Governance dan Independensi Auditor terhadap Kinerja Auditor dan Komitmen Organisasi (Survey Pada Kantor Akuntan Publik di Surakarta). Jurnal Ekonomi Bisnis dan Perbankan, 19(16), 15-29.

Satwika, A. N. \& Ramantha, I. Wa. (2015). Pengaruh Profesionalisme, Etika Profesi, dan pelatihan Auditor Terhadap Kinerja Auditor pada Kantor Akuntan Publik di Bali. E-Jurnal Akuntansi Universitas Udayana, 13(3): h:916-943. 
Sekarsari, N. (2014). Pengaruh Independensi Auditor, Komitmen Organisasi, Pemahaman Good Governance, Integritas Auditor, Budaya Organisasi, Dan Etos Kerja Terhadap Kinerja Auditor (Studi Empiris Pada Kantor Akuntan Publik di Surakarta (Doctoral dissertation, Universitas Muhammadiyah Surakarta).

Setiyadi, N. \& Rasmini, N. K. (2016). Pengaruh Gaya Kepemimpinan, Komitmen Organisasi, dan Sistem Informasi Akuntansi pada Kinerja Auditor Kantor Akuntan Publik.

Siahaan, V. D. (2010). Pengaruh Profesionalisme Terhadap Komitmen Organisasi Dalam Upaya Meningkatkan Kinerja Auditor (Studi Pada Kantor Perwakilan BPK-RI Provinsi Aceh). Jurnal Telaah dan Riset Akuntansi, 3(1), 10-28.

Sina, M. I., \& Suharnomo, S. (2013). Analisis Pengaruh Gaya Kepemimpinan Transformasional Terhadap Kinerja Karyawan dengan Komitmen Organisasi sebagai Variabel Intervening (Doctoral dissertation, Fakultas Ekonomika dan Bisnis).

Solomon, M. R. (2010). Consumer behaviour: A European perspective. Pearson education.

Somers, M. J., \& Birnbaum, D. (1998). Work-related commitment and job performance: it's also the nature of the performance that counts. Journal of Organizational Behavior: The International Journal of Industrial, Occupational and Organizational Psychology and Behavior, 19(6), 621-634. https://doi.org/10.1002/(SICI)10991379(1998110)19:6\%3C621::AID-JOB853\%3E3.0.CO;2-B

Stuart, I., \& Prawitt, D. F. (2004). The influence of audit structure on auditors' performance in high and low complexity task settings. Available at SSRN 569871.

Suseno, N. S. (2013). An empirical analysis of auditor independence and audit fees on audit quality. International Journal of Management and Business Studies, 3(3), 82-87.

Svanberg, J., \& Öhman, P. (2015). Auditors' identification with their clients: Effects on audit quality. The British accounting review, 47(4), 395-408. https://doi.org/10.1016/j.bar.2014.08.003

Szczepańska-Woszczyna, K. (2015). Leadership and organizational culture as the normative influence of top management on employee's behaviour in the innovation process. Procedia Economics and Finance, 34, 396-402. https://doi.org/10.1016/S2212-5671(15)01646-9

Tintami, P. Susanto,(2012). Pengaruh Budaya Organisasi dan gaya kepemimpinan transformasional terhadap kinerja Karyawan melalui Disiplin Kerja pada Karyawan Harian SKT Megawon II PT. Djarum Kudus.

Wardana, M. A., \& Ariyanto, D. (2016). Pengaruh Gaya Kepemimpinan Transformasional, Objektivitas, Integritas Dan Etika Auditor Terhadap Kualitas Audit. E-Jurnal Akuntansi Universitas Udayana, 14(2), 948-976.

Warren, D. E., \& Alzola, M. (2009). Ensuring independent auditors: Increasing the saliency of the professional identity. Group decision and negotiation, 18(1), 41-56. https://doi.org/10.1007/s10726-008-9123-0

Wibowo, H. A. O. (2009). Pengaruh Independensi Auditor. Komitmen Organisasi, Gaya Kepemimpinan, dan Pemahaman Good Governance terhadap Kinerja Auditor (Studi Empiris pada Kantor Akuntan Publik di Daerah Istimewa Yogyakarta).

Wijana, D. G. A., \& Ramantha, I. W. (2015). Interitas sebagai pemoderasi pengaruh komitmen organisasi pada kinerja auditor. E-Jurnal Akuntansi, 841-851.

Yucel, I., \& Bektas, C. (2012). Job satisfaction, organizational commitment and demographic characteristics among teachers in Turkey: Younger is better?. Procedia-Social and Behavioral Sciences, 46, 1598-1608. https://doi.org/10.1016/j.sbspro.2012.05.346

Yunilma. (2000). Persepsi Auditor Tentang Pengaruh Struktur Audit dan Prinsip Organisasi terhadap Konflik Peran dan Ketidakjelasan Peran, Serta Konsekuensinya. Tesis. Program Pascasarjana Universitas Gajah Mada, Yogyakarta.

Suputra, I. D. G. D. ., \& Widhiyani , N. L. S. . (2020). Types of personality, audit structure and transformational leadership styles moderate the effect of organizational commitments on auditor performance. International Research Journal of Management, IT and Social Sciences, 7(6), 54-65. https://doi.org/10.21744/irjmis.v7n6.1005 